He wanted to dedicate his "Capital" to Darwin, who, however, declined the honour without interest. Social development appeared to Marx to be essentially similar to natural evolution. Both are determined by material factors; and the individual does not count in either case, only the class. The material factors in the case of the social group are the natural resources, modes of manufacture, means of communication, etc., which constitute the social environment; and the social struggle for existence takes the form of a conflict of classes, through which progress is achieved. Marx. however, was not content to leave things to 'natural selection'. $\mathrm{He}$ resorted to fierce propaganda, fanatical agitation, and ended as the "Machiavelli of the working class movement".

Of the three characters who occupy Mr. Barzun's stage, Wagner was undoubtedly the most mischievous. He was selfish and opportunist in the highest degree; and as a born actor he managed to appear better and wiser than he was. His musicdramas, like his life, are mainly concerned with fighting, deception and adultery; and his use of old pagan legends and a creed of fatalism was a device to put at least a thin veneer of respectability on the immoral. Nietzche saw through him and denounced him. The militarists, however, found in Wagner just what they wanted, especially in his "Ring", which celebrates the superman and the triumph of German. ism, in a tale of blood, lust, and deceit. Wagnerism became a widespread cult. German soldiers and politicians fancied themselves bestriding this world like the legendary gods and heroes of Wagner's stage. They were intoxicated by Wagner's art and his artfulness, and were stimulated in the pursuit of ambitions which for the second time in a generation are threatening to devastate mankind.

Mr. Barzun's book is not entirely free from mis. takes or from an occasional tendency to journalism; but it contains a vivacious and competent discussion of many interesting problems, and may be recommended to all who are interested in our heritage of fateful ideas.

A. WOLF.

\section{ENGINEERING PEDAGOGY}

\section{Engineering Mechanics}

By Prof. S. Timoshenko and Prof. D. H. Young. Second edition. Pp. xiv +523. (New York and London: McGraw-Hill Book Co., Inc., 1940.) $28 s$.

\section{Engineering Kinematics}

By Prof. Alvin Sloane. Pp. xi+310. (New York: The Macmillan Company, 1941.) 17s. net.

$\mathrm{I}^{\mathrm{N}}$ the training of the young engineer the teacher has to look both backwards and forwards. He has to examine carefully what has been done in the past, that his students may master the detailed technique already applied successfully in these problems. In this respect he seeks to produce young men capable of dealing with issues similar to those previously solved. On the other hand, he knows that every problem is in reality a new problem with characteristics that are different from those previously encountered. For this purpose facility with technique may not in itself suffice. What may be required is a new application of fundamentals, or a search for new generalizations from the past, to be applied in a new way.

Text-books on mechanics and kinematics therefore have.two functions to fulfil. They require to present a detailed course primarily designed for improving the facility of the student in solving problems of an orthodox nature; or they may provide a reorganization of existing knowledge in new ways to throw up the underlying new principles to be found applicable to the future.

These two books, each in its own way and in its own field, deal with these separate issues. Profs. Timoshenko and Young, in this the second edition of their "Engineering Mechanics", have produced a first-rate text-book covering all the elements of statics and dynamics that fall within the scope of an orthodox set of courses-the principles of statics. concurrent and parallel forces in a plane, forces in space, virtual displacements, applications of Newton's Laws of Motion to particles and to rigid bodies, including some treatment of the gyroscope.

The illustrations throughout, although in the academic form usually associated with university courses, keep close to engineering practice. They are exhaustive, covering in each section almost every type of problem that arises, while a multitude of diagrams, clearly produced, serve to ease the development for the student. There are approximately 600 examples, many of them worked out in detail. Any student who has worked through this book will have received such a grounding in the application of orthodox dynamical principles that he will find no difficulty with the more specifically engineering problems that arise in other parts of his course. The book is excellently produced.

The other line of approach to which we have referred is stressed in Prof. Sloane's treatment of engineering kinematics. While the general headings are simple and straightforward - the rigid body, vectors, motion, displacement, velocity and acceleration-throughout the work there runs an underlying philosophical current to the book, and the fundamental concepts are critically examined and developed in a way that must be attractive and interesting to the student. Naturally a great deal of its scope is covered or implied by the previous book by Timoshenko and Young, but there is a great advantage to the budding engineer in his understanding of the principles of mechanism in being forced to study the classifications into which the multitude of mechanical devices can be subsumed. Definitions that seek to distinguish between mechanisms, machines, and instruments, for example, and so enable the wide variety of gears, cams, and linkages to be classified for their similarities and their differences, enable the author to bring out law and order throughout the whole of his text where otherwise diversity only tends to be seen. The simple headings of his chapters, already referred to, side by side with the many diverse types of illustration that fall within these heads, serve to underline this point.

It will be seen, therefore, that the particular virtue of this book lies not so much in the choice of material from the field usually covered in courses on mechanism, but rather in the pedagogical method of approach which fosters an appreciation of the common kinematical background. Like the previous book, the publishers are to be congratulated on their excellent production in paper, printing and diagrams. 